\title{
Problems Associated with Marketing of some Selected Grains in Bosso Local Government Area of Niger State
}

\author{
Usman Ramatu Kutigi \\ Department of Agricultural Economics and Extension Technology \\ Federal University Of Technology Minna, Niger State \\ E-mail: egiuk23@yahoo.com
}

\begin{abstract}
The study is aimed at determining the various problems associated with marketing of marketing of major grains in Niger State, with reference to Bosso Local Government Area. Purpose sampling techniques was use to select 100 grains marketers from four markets in the area. Data collected for analysis include socio-economic characteristics, means of transportation, and sources of supply, problems associated with grain marketing and suggestions for improving the marketing. Data collected were analyzed using description statistics, the result reveals that more female (77\%) are into marketing and $81 \%$ transport their goods using motors vehicle while presence of middlemen (40\%) is the major problem faced by the marketers. It is recommended that female adult education center should be provided, credit facilities and also good road network and luckable shops should be provided to enhance the efficient marketing of these grains.
\end{abstract}

\section{INTRODUCTION}

Grains (Rice, maize, Guinea corn and millet) are cereal which are flowering plants in the grass family (Graminacae). They are cultivated mostly for their feed value (Lawani and Babaleye 1998). Nigeria has a total land area of 924 or 73.7 million hectares and this is considered to be suitable for cultivation. Crops occupy roughly $34 \%$ or 25 million hectare of total devoted to cultivation. Out of this, grains alone occupy $52 \%$ or 13 million hectare with a combined production figure of 15,303 million tones in 1989 (Lawani and Babaleye, 1998). These grains according to them contributed to the economy of Nigeria in several ways, these include; Gross Domestic Product, Food requirement of Nigeria, Employment, Income to the farming community, Raw materials for human and industries, Home consumption.

Marketing may be thought of as simply the process of making goods available for consumption., it covers all business functions including decision making. Arene (1998) define agricultural marketing as the legal, physical and economic services that make it possible for products from producers to get to consumers in the desired form.

According to Arena (1998) agricultural marketing can be define as all the legal, physical and economic services that make it possible for products from the producers to get to the consumer in the form desired by consumers. On the other hand, Abbort and Makahan (1990) discussed that marketing of agricultural produce begins at the farm when the farmer plan his production to meet specific demands and market prospects. The characteristics features of agricultural products according to Adeyeye and Dittoh (1986) are; high perishablility, bulkiness, seasonal production and inelastic of demand and supply. 
Journal of Agricultural Extension

Vol. 13 (2) December 2009

Problems of marketing agricultural products has been a major constraint to the development of agriculture in Nigeria. These problems amongst others are:

1. Production condition: One of the most persistent obstacles to the development of agriculture in the tropics and indeed Nigeria is the source of supply, (Abbott and Makaham 1990). In many areas agricultural commodities are produced on small sized farms scattered throughout the country, (Adegeye and Dittoh 1986).

2. Inadequate transport facilities: The major problem of agricultural marketing is that transport facilities are grossly inadequate. Famoroti (1998) observe that most feeder roads are unsurfaced, narrow, poorly drained and winding.

3. Absence of uniform measures and weights: It is a great problem in most of our markets, since the measures are of different types and sizes (Adegeye and Dittoh, 1986).

4. Inadequate storage and warehousing facilities: Inadequate storage facilities are the causes of heavy loses of agricultural produce in many part of the world. The problem of inappropriate on-farm storage facilities leads to wastage of farm produce (Olukosi, et al 2007).

Other problems are price instability of agricultural produce, irregular flow of market information, inadequate fund for marketing and also according to Olukosi et al 2007, observed that the extension service delivery system is still inadequate and especially women extensionist are very limited to handle gender issues. These therefore posed a serious problem to marketing of agricultural produce.

\section{Objectives of the study}

The broad objective of this study is to determine the various problems facings grains marketing in the study area. However, specific objectives ate to:

1. determine the socio - economic characteristics of the respondents.

2. determine the marketing channel of grains

3. identify the problems faced in marketing by respondents

4. to make necessary recommendations based on result of the findings of the study.

\section{METHODOLOGY}

The study area of this research is Bosso L G A Niger state. The local government has a total land area of 1,606.143 square kilometer with a population of 90,397 people according to 1999 population census, and a projected population of 124,004 in 2004 (Niger state statistical year book 2004). Niger state is carved out of the farmer North-western states in 1976; it however came into being on the $1^{\text {st }}$ April, 1976. The state was constitutionally administered under nine (9) local government areas but now has Twenty five (25) local government areas. It lies between latitude 30.20 East and longitudes 80 and 10.30 North. It is boarded to the North by Sokoto State, West by Kebbi State, South by Kogi State and South-West by Kwara State, Kaduna State and the Federal capital Territory boarder the state both to the North East and South-East respectively. Niger state is situated in the middle belt zone of the country. The state is indispensable one of the largest fertile agricultural lands in Nigeria. 
The population for the study includes grain (i.e. rice, maize, guinea corn and millet) sellers in Bosso metropolis market, Maikunkele, Beji and Garatu markets all in Bosso L.G.A. there are different sections in the markets, the grain sellers section was chosen and questionnaires were administered to the respondents randomly, the sample size for the study is one hundred (100) with 25 respondent each for Bosso and Maikunkele markets, 35 and 15 for Beji and Garatu markets respectively. The variation in the number of respondents in different markets is due to the difference in size and population of the markets. The data were analyzed using descriptive statistics (such as bar chart and percentages).

\section{RESULTS AND DISCUSSION}

From Table 1, it can be deduced that most of the respondents are female $(77 \%)$. This implies that more female are into marketing of grain when compared with the male counterpart who mostly engage in farming rather than marketing. The extension implication is that there is need for more female extensionist who can educate these marketers on how to achieve effective marketing. And the highest percentage of respondents $(42 \%)$ are in the age range of $31-41$ years and $41-50$ years is (39\%) which means that the youngest age groups shy away from marketing to either school or white color jobs. The table also reveals that $42 \%$ of the respondents have no formal education and $12 \%$ have Quranic education, this means that a total of $54 \%$ of the respondents are not formally educated and this hinders the effectiveness of marketing as they find it difficult to communicate easily with the buyers.

Furthermore Table 1 shows that most of the respondents are retailers (60\%)that is they sell in small quantities mostly in "mudu" to consumers or petty traders and only $4 \%$ of the respondent are wholesalers who sell in bags to the retailers. Half of the respondents $(50 \%)$ sell or market all the four (rice, maize, guinea corn and millet) grains together, which means most of the respondents hardly market a single grain, rather they prefer marketing all together so that the little gains can add up to something at the end.

"Experience being the best teacher", a number of the markers are quite experience. That is to say the marketing of these grains a bit profitable otherwise they will have quite to something else, because the longer one stays in a business means the business is profitable. 
Journal of Agricultural Extension

Vol. 13 (2) December 2009

TABLE 1: The Socio-Economic Characteristics of Respondents

\begin{tabular}{|c|c|c|}
\hline Item & Frequency & Percentage (\%) \\
\hline \multicolumn{3}{|l|}{ Gender } \\
\hline Male & 23 & 23 \\
\hline Female & 77 & 77 \\
\hline \multicolumn{3}{|l|}{ Age Group (Years) } \\
\hline $11-20$ & 2 & 2 \\
\hline $21-30$ & 9 & 9 \\
\hline $31-40$ & 42 & 42 \\
\hline $41-50$ & 39 & 39 \\
\hline Above 50 & 8 & 8 \\
\hline \multicolumn{3}{|l|}{ Educational Level } \\
\hline Primary & 31 & 31 \\
\hline Secondary & 13 & 13 \\
\hline Post-Secondary & 2 & 2 \\
\hline Quranic & 12 & 12 \\
\hline No education & 42 & 42 \\
\hline \multicolumn{3}{|l|}{ Types of Seller } \\
\hline Wholesaler & 4 & 4 \\
\hline Retailer & 60 & 60 \\
\hline Wholesaler/Retailer & 36 & 36 \\
\hline \multicolumn{3}{|c|}{ Types of Grain Marketed } \\
\hline Rice & 10 & 10 \\
\hline Maize & 17 & 17 \\
\hline Guinea Corn & 15 & 15 \\
\hline Millet & 8 & 8 \\
\hline All the four grains & 50 & 50 \\
\hline \multicolumn{3}{|c|}{ Years of Experience (Years) } \\
\hline $1-5$ & 15 & 15 \\
\hline $6-10$ & 25 & 25 \\
\hline $11-15$ & 28 & 28 \\
\hline Above 15 & 32 & 32 \\
\hline
\end{tabular}

\section{Sources of supply}

The sources of supply of respondents from table 2 shows that $40 \%$ of respondents get supplies from middlemen and $22 \%$ of the respondents get theirs from both middlemen and farmers. This shows that bulk of the supplies is by middlemen who sell at higher prices than the farmers, the implication is that the farmers get less profit than the middlemen. 
TABLE 2: Sources of Supply of Respondents

\begin{tabular}{lcc}
\hline \multicolumn{1}{c}{ Source } & Frequency & Percentage \\
\hline Farmers & 30 & 30 \\
Middlemen & 40 & 40 \\
Farmers/middlemen & 22 & 22 \\
Government stock & 2 & 2 \\
Others (personal farms) & 6 & 6 \\
\hline TOTAL & 100 & 100 \\
\hline
\end{tabular}

Source: Field survey, 2006

\section{Marketing Channel}

Marketing channel according to Baba (2004) can be viewed as path which a product or commodity pass as if makes from producers to consumers. It indicates how the various market participants are organized to accomplish the movement of product from the producer to the final consumer.

\section{Marketing Channel According to the Respondents}

Producers

Local Assembles

Wholesaler

Retailers

Consumers

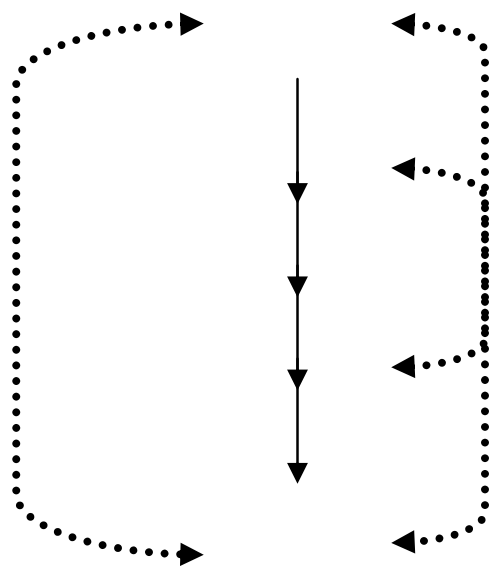

Fig 1: Marketing channel for grains in the study area:

The various participants from figure are;

1. The producers: This is the farmers that produce the grains, they initiate the marketing process, they usually sell in bulk.

2. Local assembler: They buy and sell grain crops at local level. They buy from individual farmers and sells in larger rural markets.

3. Wholesalers: They buy in large quantity from the local assemblers or directly from the farmers and they sell in small quantities to other buyers. 
Journal of Agricultural Extension

Vol. 13 (2) December 2009

4. Retailers: They sell produce in urban and rural market in small quantities to the consumers. Retailers who constitute the largest number of inter-mediaries; perform the marketing function of bulk breaking (In service training papers, 1994).

5. Consumers: They are the final people in the marketing channel, they end the marketing function, and they mostly buy in small quantity for their own consumption.

\section{Means of Transportation Products}

Transportation is the movement of goods from one place to another. Transportation of agricultural produce is not easy due to its bulkiness, perishability etc certain amount of loses are encured. Table 3 revealed that almost all the respondents $(81 \%)$ transport their products by using motor vehicle that is either lorry or bus. This most available means of transportation in the study area are buses and Lorries which are quite expensive $10 \%$ of the respondents used other means of which most of them used wheelbarrow and their heads to convey their product to the market, especially the people that live close to the market.

TABLE 3: Means Of Transportation of Products by Respondents

\begin{tabular}{lcc}
\hline \multicolumn{1}{c}{ Means } & Frequently & Percentage (\%) \\
\hline Motor vehicle (lorry/ bus) & 81 & 81 \\
Motor cycle & 9 & 9 \\
Train & - & - \\
Other & 10 & 10 \\
\hline
\end{tabular}

\section{Problems of Transportation}

Grain marketers are faced with the transportation of their products to the market. Famorati, (1998) observed that most feeder road are unsurfaced, narrow, poorly drained and winding. Table 4 shows that $(30.5 \%)$ of the respondents complained of motorable but bad roads. That is the roads are untarred and motorist find it difficult to move on it especially during rainy season. (36.9\%) complained of high cost of transportation which is occurred to high fuel price as complained by the driver. The table shows that there were multiple responses by respondent base on the problems they encountered. 
TABLE 4: Problems of Transportation by Respondent

\begin{tabular}{lcc}
\hline Problems & Frequency & Percentage (\%) \\
\hline No motorable road & 12 & 5.9 \\
Motorable but bad road & 62 & 30.5 \\
Insufficient vehicle & 54 & 26.6 \\
High cost of transportation & 75 & 36.9 \\
\hline
\end{tabular}

"Indicate multiple responses

\section{Problems Encountered In Buying And Selling Of Grains by Respondent}

Problems are definitely inevitable in any business marketing of grains is not an exception. There are different challenges faced by marketer in the process of marketing their products. Some of the problems are presented in table 5 . Table 5 shows that $40 \%$ of the respondents are faced by problem of middlemen. This implies that activities of middlemen hinder direct access of the grains by marketer from farmers.6\% of respondents are faced by other problems such as co-operative charges, inadequate storage facilities, inadequate information about market situations etc.

TABLE 5: Problems Of Marketing Grains by Respondents

\begin{tabular}{lcc}
\hline Problems & Frequency & Percentage (\%) \\
\hline Transportation & 56 & 28.0 \\
Presence of middlemen & 80 & 40.0 \\
Language barriers & 32 & 16.0 \\
Different measuring device & 20 & 10.0 \\
Others & 12 & 6.0 \\
\hline
\end{tabular}

* Indicate multiple responses 
Journal of Agricultural Extension

Vol. 13 (2) December 2009

\section{Ways of Improving Grain Marketing}

The grain (Rice, Maize, Guinea corn and Millet) marketers after identifying their problems were asked the area they needed supports to enhance their marketing activities. The suggestions are presented in the table below. Table 6 , revealed that $36.4 \%$ of the respondents suggested that good accessible road should be constructed especially from the rural areas where they purchase their products to the urban centers where these products are sold. A link between the rural and urban centers through good road network will ease the transportation problem

On the other hand $31.8 \%$ of the respondents suggested other ways of improving the marketing of this grains This includes provision of credit facilities by financial institutions will enable them have capital to purchase in bulk and sell to consumer at any time, provision of lockup stores/shops in the market places so that they can be able to leave the remaining grains in the shops at the end of the day, provision of subsidy on petroleum products so as to reduce the cost of transportation.

TABLE 6: Ways of Improving Marketing Operations by Respondents

\begin{tabular}{lcc}
\hline Ways & Frequency & Percentage (\%) \\
\hline Provision of good roads & 80 & 36.4 \\
Efficient marketing information & 40 & 18.2 \\
Creation of market & 30 & 13.6 \\
Others & 70 & 31.8 \\
\hline
\end{tabular}

*Indicate multiple responses.

\section{SUMMARY CONCLUSION AND RECOMMENDATIONS}

The study revealed that all market in the study is characterized by marketers selling more than one type of the grain at a time and transportation and middlemen are the major constraint to marketing of the grains. It is recommended that credit facilities should be provided to the marketers by financial institutions or related bodies, lock-up shops should be provided in the markets so that the marketers can leave the remaining goods and female adult education centers should be provided to enhance the marketing of grains in the study area. 


\section{Journal of Agricultural Extension \\ Vol. 13 (2) December 2009}

\section{REFERENCES}

Abbott, J.C. and Makaham J.P (1990), Agricultural Economic and marketing in the Tropics, Longman Group Limited.

Adegeye, A.J and J.S Dittoh (1986), Essentials of Agricultural Economics, impact Publishers Nigeria Ltd, Ibadan. Pp 164-167.

Arena, C. O (1998), introduction to Agricultural Marketing Analysis for Development Economics Fuuadu Nsukka.

Baba, K.M. (2004), Agricultural marketing Lecture Note, 2004. Department of Agricultural Economic and extension Technology (Unpublished) F.U.T Minna.

Famorati, S. (1998), the impact of rural infrastructural Facilities in Agricultural product and marketing. A case study of Ekiti Unpublished b. Sc project Department of Agricultural economics, University of Ibadan

In-service training Papers (1994), A.B.U Zaria.

J. O. Olukosi, S. U. Isitor and O. Ode (2007) Agricultural Marketing and Prices: Principles and Applications, $3^{\text {rd }}$ edition. Living books series GU publications Abuja. Pp6-7.

Lawani S. M. and Babaleye T (1998) Recent Development In cereals production in Nigeria.

Niger State Statistical year book (2004).

Olayide, S. O. (1998) Economic of inter state marketing of farm products: A special analysis of transport cost, building of Rural economic and sociology vol. 4 No. 2. 